\section{Journal of Polytechnic POLITEKNK DERGISI}

\section{POLITEKNIK DERGISI}

JOURNAL Of POLYTECHNIC

\title{
Identification of critical values based on natural ester oils as potential insulating liquid for high voltage power transformers
}

Yüksek gerilim güç transformatörleri için potansiyel yalıtım sıvısı olarak doğal ester yağlarına dayalı kritik değerlerin tespit edilmesi

Yazar(lar) (Author(s)): Nihat PAMUK

Bu makaleye șu ssekilde atıfta bulunabilirsiniz (To cite to this article): Pamuk N., " Identification of critical values based on natural ester oils as potential insulating liquid for high voltage power transformers, Politeknik Dergisi, 20(4): 869-877, (2017).

Erișim linki (To link to this article): http://dergipark.gov.tr/politeknik/archive DOI: $\quad 10.2339 /$ politeknik.369050 


\title{
Identification of Critical Values Based on Natural Ester Oils as Potential Insulating Liquid for High Voltage Power Transformers
}

\author{
Araştırma Makalesi / Research Article \\ Nihat PAMUK \\ Turkish Electricity Transmission Company, Sakarya, Turkey \\ (Geliş/Received : 24.06.2016 ; Kabul/Accepted : 03.10.2017 )
}

\begin{abstract}
This study tries to bring a complex summary of properties of natural ester fluids from the point of view of electrical insulation fluid for high voltage power transformers. Although many papers have been published in this area, this study try to address some less known problems which however plays a key role in new fluid practical applications. Some differences compared to mineral oils are discussed in study. The critical values that might occur in the future for industrial applications are proposed, evaluated and discussed.
\end{abstract}

Keywords: Natural esters, insulating liquid, power transformer, mineral oils.

\section{Yüksek Gerilim Güç Transformatörleri için Potansiyel Yalıtım Sıvısı Olarak Doğal Ester Yağlarına Dayalı Kritik Değerlerin Tespit Edilmesi}

ÖZ

Bu çalışma, elektriksel yalıtım akışkanları açısından yüksek gerilim güç transformatörleri için, doğal ester akışkan özelliklerinin karmaşık bir özetini çıkarmaya çalışmaktadır. Bu alanda birçok makale basılmış olmasına rağmen, bu çalışma yeni akışkan pratik uygulamalarında kilit bir rol oynayan ancak daha az bilinen bazı sorunları belirtmeye çalışmaktadır. Çalışmada, mineral yağlarla kıyaslanan bazı farklılıklar gösterilmiştir. Endüstriyel uygulamalar için, gelecekte oluşabilecek kritik değerler önerilmiş, değerlendirilmiş ve tartışılmışır.

Anahtar Kelimeler: Doğal esterler, yalıtım sıvısı, güç transformatörü, mineral yağlar.

\section{INTRODUCTION}

The oiled-paper electrical insulation system is crucial for many power engineering applications. Particularly, oiled-paper system virtually allows power transformer voltage level and power transformer new design. Mineral oils are mainly used for these power engineering applications. However, these applications are complicated issue by their uncertain degradation. They have negative impact on the environment and human health. In the concept of the European Union (EU) are also virtually no mineral oil resources. Therefore, other options are searched to either fully or partially replace mineral oils by renewable resources. An enormous effort was done in this crucial area and some perspective alternatives were chosen during the last decade. But further research is necessary for industrial use. Principally methodology of evaluation and criteria parameters must be set to ensure highest reasonable

*Sorumlu Yazar (Corresponding Author)

e-posta:nihatpamuk@gmail.com reliability of power transformers filled with such an insulating liquid. High voltage power systems operator is specially concern not only some of their different characteristic parameters of new insulating liquids but also standardized limit values for industrial use.

\section{DESCRIBING INSULATION FLUIDS FOR POWER TRANSFORMER}

In principle, two perspective ways of searching suitable insulating liquids are possible. The first has a basis in chemical industry. In laboratory conditions were synthesized substances with convenient insulating properties and sufficient biodegradability simultaneously. On the other hand, it was proven, that appropriate fluids may be found in nature [1]. Vegetable oils (natural based esters) exhibit suitable properties in some aspects and some limitations in other [2-3]. Further research is focused on finding additives to improve particular negative characteristics. In table 1 some common known features of electro insulating fluids are compared [4]. Natural esters have some outstanding 
properties in comparison with mineral or synthetic oils The first excellent properties are low flammability (flash point min. $300{ }^{\circ} \mathrm{C}$ ). Another one is a very good biodegradability (vegetable oil e.g. sunflower oil is fully biodegradable after 7 days). Other properties are not significantly different and are sufficient for industrial molecule was easily bonded with natural ester, weakening the hydrolysis process of cellulose. Cellulose is chemically modified by natural ester during thermal aging process. This study suggests that determining the difference of aging period between natural ester and mineral oil should be used factor. So it is possible to

Table 1. Comparison of insulating fluids [4]

\begin{tabular}{|c|c|c|c|}
\hline Fluid/Parameter & Synthetics & Mineral & Natural \\
\hline Moisture Saturation & High & Low & High \\
\hline DPP of Kraft Paper & - & Linear Trend & Exponential Trend \\
\hline Pour Point & Low/Semi/High & Low/Semi & High/Semi \\
\hline Flash Point & High & Low & High \\
\hline Acidity & Low/Semi/High & Low & Semi \\
\hline Permittivity & Low/Semi & Low & Acceptable \\
\hline Viscosity & High & Low & High \\
\hline Toxicity & Low/Semi/High & Semi/High & Low \\
\hline Dissipation Factor & Low/Semi & Low & Very Low \\
\hline Water Content & Very Low & Low & Low/Semi \\
\hline Oxidation Stability & Low/Semi/High & High & Very High \\
\hline Biodegradability & Low/Semi/High & Very Low & High \\
\hline Breakdown Voltage & High & High & \\
\hline
\end{tabular}

application according to requirements, but it is necessary to do some improvement.

The aim of the study is presented for aging model of IEEE and IEC standards using biodegradability model of oil-immersed power transformer for natural ester and mineral oil. Aging model of the power transformer is based on thermal - electrical analogy that is calculated separately for natural and mineral oils covering top-oil and hot-spot temperatures. The hot - spot temperature values each ester oil are used to calculate aging parameters which include the aging acceleration factor, time dependent relative aging rate and insulation life loss variations. In literature, also there are more studies about natural ester and mineral oil. Moisture effects on the electric breakdown strength of transformers boards under voltage in oil are examined. Natural ester has higher absolute humidity and acidity during the long ageing period. Power transformer paper in vegetable oil had larger activation energy. Due to the larger interaction force between water and natural ester molecules, water predict the lifetime of natural ester oil - immersed power transformers easily and nearly correct.

\section{CHEMICAL STRUCTURE OF NATURAL ESTER OILS}

When searching material with appropriate electro insulating properties, the first sight must focus on its chemical structure. An ideal electrical insulating fluid is non-polar; hence the dielectric losses by polarization are limit close to zero [5]. Traditionally used mineral oils are slightly polar, very close to ideal fluids. Their dissipation factor is given by conductivity, which rises with temperature [6]. On contrary vegetable oils (proposed substitutes) are based on ester bonds, which are in general polar. This is also reason why they can absorb significantly greater moisture content than mineral oils. Natural based esters are glycolipids esters of fatty acids, as shown on figure 1 .

Common natural oils have similar chemical structure, but differ in particular fatty acid ratios. Synthetic esters for

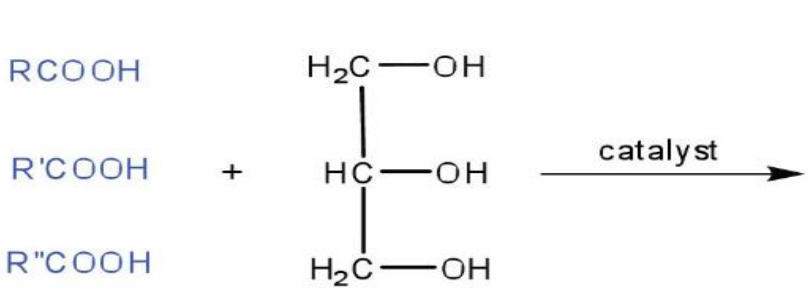

Three fatty acids

\section{Glycerol}<smiles>[R]C(=O)OCC(COC([R])=O)OC([R])=O</smiles>

Triglyceride

Figure 1. The chemical model for triglyceride genesis 
electrical insulation purposes are synthesized in various structures which is hard to generalize. Recently the most promising esters are based on pentaerythritol [7]. Pentaerythritol chemical model is shown on figure 2.<smiles>CCCCC(CC)C(=O)OCC(COC(=O)C(CC)CCCC)(COC(=O)C(CC)CCCC)COC(=O)C(CC)CCCC</smiles>

Figure 2. The chemical model for pentaerythritol

However, some common features can be observed. Usually short chain compounds are chosen, hence they ensure low viscosity. Also biodegradability depends on molecular complexity. Shorter molecular chains are better biodegradable.

\section{IDENTIFICATION OF CRITICAL VALUES}

Experimental work demonstrated great differences of particular insulating fluid on behavior of whole paper-oil system [8-9]. For traditionally used mineral oils its behavior with cellulose elements is well known and criteria for use are set in standard IEC 60422/2013 [10].

The standard is dividing properties to three categories as follows:

* Good factor sequences of values detected as per IEC $60422 / 2013$ for the factor as a good situation and it is feasible to provide the present gap for exemplification.
Executively factor sequences of values detected as per IEC 60422/2013 for the factor as a executively situation and it is hence essential to progress to the common receiving patterns, respectively to control other connected factors.

Bad factor sequences of values detected as per IEC $60422 / 2013$ for the factor as an insufficiently condition and it is hence essential to salvage oil factors by barter or regeneration.

The IEC 60422/2013 standard also characteristics the time gap for receiving oil patterns. The gap is attached to the condition of fluid. The critical values are disunited as per the kind of implementation and the nominal voltage $\left(\mathrm{V}_{\mathrm{n}}\right)$ of the instruments for each class. High voltage power transformer values are dedicated to the class;

\# Class number is 1 , and it is shown $\left(\mathrm{V}_{\mathrm{n}}>420 \mathrm{kV}\right)$ voltage values,

Class number is 2 , and it is shown $\left(170 \mathrm{kV}<\mathrm{V}_{\mathrm{n}}<\right.$ $420 \mathrm{kV}$ ) voltage values,

\& Class number is 3 , and it is shown $\left(72.5 \mathrm{kV}<\mathrm{V}_{\mathrm{n}}<\right.$ $170 \mathrm{kV}$ ) voltage values,

Medium voltage power transformer value is dedicated to the class;

\& Class number is 4 , and it is shown $\left(\mathrm{V}_{\mathrm{n}}<72.5 \mathrm{kV}\right)$ voltage values.

The last class (number 4) is characterized with distribution transformers. However, for alternative fluids it is not possible to use the same criteria as for mineral oils, because of different nature and behavior of the fluids. First attempts of unification and evaluation of natural and synthetic esters were set in standards. However, these values greatly differ over each standard (EN, IEC, IEEE, ASTM, etc.) or company recommendation. Recommended values of important parameters of transformer oil according to valid

Table 2. Suggested limit values for novel rock oil according to EN60422 [11]

\begin{tabular}{|c|c|c|c|c|}
\hline \multirow{2}{*}{ Parameter } & \multirow{2}{*}{ Standard } & \multicolumn{2}{|c|}{ The voltages in each class (kV) } \\
\cline { 3 - 5 } & Class 4 & Class 3 & Class 2 \\
\hline $\begin{array}{c}\text { Dissipation Factor } \\
90{ }^{\circ} \mathrm{C}(-)\end{array}$ & EN 60247 & $\mathrm{V}_{\mathrm{n}} \leq 0.015$ & $\mathrm{~V}_{\mathrm{n}} \leq 0.015$ & $\mathrm{~V}_{\mathrm{n}} \leq 0.010$ \\
\hline $\begin{array}{c}\text { Breakdown Voltage } \\
2,5 \mathrm{~mm}(\mathrm{kV})\end{array}$ & $\mathrm{EN} \mathrm{60156}$ & $\mathrm{V}_{\mathrm{n}}>55$ & $\mathrm{~V}_{\mathrm{n}}>60$ & $\mathrm{~V}_{\mathrm{n}}>60$ \\
\hline $\begin{array}{c}\text { Water Content } \\
(\mathrm{mgH} \text { O/kg) }\end{array}$ & EN 60814 & $\mathrm{V}_{\mathrm{n}}<20$ & $\mathrm{~V}_{\mathrm{n}}<10$ & $\mathrm{~V}_{\mathrm{n}}<10$ \\
\hline $\begin{array}{c}\text { Acid Number of Oil } \\
(\mathrm{mgKOH} / \mathrm{g})\end{array}$ & $\mathrm{EN} \mathrm{62021-1}$ & $\mathrm{V}_{\mathrm{n}} \leq 0.03$ & $\mathrm{~V}_{\mathrm{n}} \leq 0.03$ & $\mathrm{~V}_{\mathrm{n}} \leq 0.03$ \\
\hline $\begin{array}{c}\text { Resistivity } \\
90{ }^{\circ} \mathrm{C}(\mathrm{G} \Omega . \mathrm{m})\end{array}$ & $\mathrm{EN} \mathrm{60247}$ & $\mathrm{V}_{\mathrm{n}}>60$ & $\mathrm{~V}_{\mathrm{n}}>60$ & $\mathrm{~V}_{\mathrm{n}}>60$ \\
\hline
\end{tabular}


Table 3. Suggested limit values for used rock oil according to EN60422 [11]

\begin{tabular}{|c|c|c|c|c|}
\hline \multirow{2}{*}{ Parameter } & \multirow{2}{*}{$\begin{array}{c}\text { Class } \\
\text { Number }\end{array}$} & \multicolumn{3}{|c|}{ The recommended limit values $(\mathrm{kV})$} \\
\hline & & Good & Medium & Bad \\
\hline \multirow{2}{*}{$\begin{array}{l}\text { Dissipation Factor } \\
90{ }^{\circ} \mathrm{C}(-)\end{array}$} & $1-2$ & $\mathrm{~V}_{\mathrm{n}}<0.10$ & $0.10<\mathrm{V}_{\mathrm{n}}<0.20$ & $\mathrm{~V}_{\mathrm{n}}>0.20$ \\
\hline & 3 & $\mathrm{~V}_{\mathrm{n}}<0.10$ & $0.10<\mathrm{V}_{\mathrm{n}}<0.50$ & $\mathrm{~V}_{\mathrm{n}}>0.50$ \\
\hline \multirow{2}{*}{$\begin{array}{c}\text { Breakdown Voltage } \\
2,5 \mathrm{~mm}(\mathrm{kV})\end{array}$} & $1-2$ & $V_{n}>60$ & $50<V_{n}<60$ & $\mathrm{~V}_{\mathrm{n}}<50$ \\
\hline & 3 & $\mathrm{~V}_{\mathrm{n}}>50$ & $40<V_{n}<50$ & $\mathrm{~V}_{\mathrm{n}}<40$ \\
\hline \multirow{2}{*}{$\begin{array}{c}\text { Water Content } \\
\left(\mathrm{mgH}_{2} \mathrm{O} / \mathrm{kg}\right) 20{ }^{\circ} \mathrm{C}\end{array}$} & $1-2$ & $\mathrm{~V}_{\mathrm{n}}<5$ & $5<V_{n}<10$ & $\mathrm{~V}_{\mathrm{n}}>10$ \\
\hline & 3 & $\mathrm{~V}_{\mathrm{n}}<5$ & $5<V_{n}<10$ & $\mathrm{~V}_{\mathrm{n}}>15$ \\
\hline \multirow{2}{*}{$\begin{array}{l}\text { Acid Number of Oil } \\
\qquad(\mathrm{mgKOH} / \mathrm{g})\end{array}$} & $1-2$ & $\mathrm{~V}_{\mathrm{n}}<0.10$ & $0.10<\mathrm{V}_{\mathrm{n}}<0.15$ & $\mathrm{~V}_{\mathrm{n}}>0.15$ \\
\hline & 3 & $\mathrm{~V}_{\mathrm{n}}<0.10$ & $0.10<\mathrm{V}_{\mathrm{n}}<0.20$ & $\mathrm{~V}_{\mathrm{n}}>0.20$ \\
\hline \multirow{2}{*}{$\begin{array}{c}\text { Resistivity } \\
20{ }^{\circ} \mathrm{C}(\mathrm{G} \Omega . \mathrm{m})\end{array}$} & $1-2$ & $\mathrm{~V}_{\mathrm{n}}>200$ & $20<V_{n}<200$ & $\mathrm{~V}_{\mathrm{n}}<20$ \\
\hline & 3 & $V_{n}>60$ & $4<V_{n}<60$ & $\mathrm{~V}_{\mathrm{n}}<4$ \\
\hline \multirow{2}{*}{$\begin{array}{c}\text { Resistivity } \\
90{ }^{0} \mathrm{C}(\mathrm{G} \Omega . \mathrm{m})\end{array}$} & $1-2$ & $\mathrm{~V}_{\mathrm{n}}>10$ & $1<\mathrm{V}_{\mathrm{n}}<10$ & $\mathrm{~V}_{\mathrm{n}}<1$ \\
\hline & 3 & $\mathrm{~V}_{\mathrm{n}}>3$ & $0.2<\mathrm{V}_{\mathrm{n}}<3$ & $\mathrm{~V}_{\mathrm{n}}<0.2$ \\
\hline
\end{tabular}

standards are shown in table 2 and table 3 respectively [11].

In this instance of some factors of used rock oils (for example $\tan \delta$ ) are circumscribes adjust upper value, as shown by the conclusions of heat-treated rock oil. So, it is suitable to use the dissipation parameter boundary value suggested by IEC 60422/2013 standard for a novel rock oil, ie. $1.5 \%$. In the case of perspective oil is still missing a complete and unified overview applicable for power transformers based on IEC standards. Here are described some currently available standards for determining the values of criteria focusing on IEC standards and suggests a suitable equivalent values, including the possible approaches applicable for power transformers according to category of nominal voltage (Class 1, Class 2, and Class 3). Liquids based on organic and synthetic esters are described in Standard IEC $1203 / 1905$

The IEC 1203/1905 standard concentrates on the practice of non-rock oil on distribution power transformers with rated voltage up to $36 \mathrm{kV}$ [12]. Isolation fluids occur synthetic organic esters are separated into three categories [13].

* Isolation fluids appropriate for regular process. For the practice of high voltage power transformers are characterized factor values listed in table 4 [14].

* Esters, which are to be regulated by a suitable recover method that they can be worked in the electrical power equipment.

Unusable esters.

Table 4. The compared parameter values according to IEC 1203/1905 [12] and according to IEC 61099/2010 [14]

\begin{tabular}{|c|c|c|}
\hline Parameter & $\begin{array}{c}\text { IEC 1203/1905 } \\
\text { Standard [12] }\end{array}$ & $\begin{array}{c}\text { IEC 61099/2010 } \\
\text { Standard [14] }\end{array}$ \\
\hline Dissipation Factor $20^{\circ} \mathrm{C}(-)$ & $\leq 0.01$ & $\leq 0.03$ \\
\hline Breakdown Voltage $2,5 \mathrm{~mm}(\mathrm{kV})$ & $>30$ & $\leq 45$ \\
\hline Water Content $\left(\mathrm{mgH}_{2} \mathrm{O} / \mathrm{kg}\right) 20^{\circ} \mathrm{C}$ & $\leq 400$ & $\leq 0.30$ \\
\hline Acid Number of Oil $(\mathrm{mgKOH} / \mathrm{g})$ & $\leq 2.0$ & $\geq 2$ \\
\hline Resistivity $20^{\circ} \mathrm{C}(\mathrm{G} \Omega . \mathrm{m})$ & $\geq 6$ & $\geq 35$ \\
\hline Viscosity $\left(\mathrm{mm}^{2} / \mathrm{s}\right) 40{ }^{\circ} \mathrm{C}$ & - & $\geq 300$ \\
\hline Fire Point $\left({ }^{\circ} \mathrm{C}\right)$ & $>300$ & \\
\hline
\end{tabular}




\section{KINEMATIC VISCOSITY AND FLASH POINT}

Insulating liquids in power transformer fulfill insulating function. As oil is heated by winding and core losses, they move and circulate over power transformer tank and radiators. This so called thermo siphon effect yields thermal transfer and enables higher loading. When alternative insulating fluids are concerned for use, their cooling properties must be considered. For usable alternative liquids heat transfer coefficient and thermal capacity are similar [15]. The greatest difference is in case of viscosity. The higher is the viscosity, the worse are cooling abilities. The topic is even more complicated, because the nature of flow is changing from turbulent to laminar and cooling is limited even more. The viscosity depends on chemical structure. A general idea is that the more complex is molecular chain, the greater is the viscosity. Hence natural oils are cleaving into monoesters with linear molecular chains. In case of synthetic esters, the required properties are achieved by blending suitable compounds, thus low molecular chains are picked. Furthermore, it is necessary to examine viscosity dependence on temperature. Especially natural esters tend to freeze in temperature range -10 to $-27^{\circ} \mathrm{C}[16]$.

A great number of power transformers may approach such a low temperature during operations, thus additional actions for lowering the pour point must follow. There are depressants which may improve the pour point of subjected liquid. The other way is to modify vegetable oil by shortening its chains. One of the three fatty acid chains in natural ester molecule may be exchanged for a shorter acetate chain, which yields lowering the viscosity [15]. Also decomposition of natural ester to mono ester compounds leads to lowering the viscosity [17]. On the other side of temperature scale, flash point is also evaluated. Natural and synthetic esters have in general higher flash point than mineral oils, so there is no improvement necessary. Pure point and flash point goes usually "hand in hand" both up or both down, so fluids with very low pure point has ales low flash point. In the case of esters, researcher can by lowering pure point loose partially fire safety feature. In case of viscosity and pour point respectively, power transformer operators will follow current regulations. In the case of natural esters, researcher must strive to these values as closely as possible.

\section{DIELECTRIC PROPERTIES OF MINERAL OIL}

For proper function, alternative fluid must satisfy all required dielectric parameters. These are breakdown voltage, dissipation factor, permittivity and resistivity. The breakdown voltage value according to IEC standards should be higher than 30 or $45 \mathrm{kV} / 2.5 \mathrm{~mm}$ (for distribution power transformer) [14]. It was proved, that common pure natural esters fulfill this requirement when they are dried (also in table 5). However, this may not be valid for ester mixtures, especially with particular additives.
Table 5. The breakdown voltage values according to high temperature degree [14]

\begin{tabular}{|c|c|c|}
\hline $\begin{array}{c}\text { Breakdown Voltage } \\
\mathbf{2 , 5} \mathbf{~ m m ~ ( k V ) ~ / ~ T e m p e r a t u r e ~}\end{array}$ & $\begin{array}{c}\text { Soybean } \\
\text { Oil }\end{array}$ & $\begin{array}{c}\text { Palm } \\
\text { Oil }\end{array}$ \\
\hline $20^{\circ} \mathrm{C}$ & 61 & 63 \\
\hline$-5^{0} \mathrm{C}$ & 59 & - \\
\hline$-14^{\circ} \mathrm{C}$ & 55 & - \\
\hline$-27^{\circ} \mathrm{C}$ & 57 & 59 \\
\hline
\end{tabular}

The dissipation factor of ester insulating fluids greatly differs from rock oil. Rock oils are non-polar or very lightly polar materials, that electron neutralization is an overpowering mechanism of neutralization. So, dissipation parameter of rock oils at 60 loops is made by conductivity that increases with high temperature degree. However, when comparing with inherent based on esters (palm oil): it is known that inherent based on esters are robustly polar materials, where dipole neutralization takes principal act in electron losses.

Hence dissipation parameter is importantly higher than of rock oils. The dissipation parameter of inherent based on esters are affected either by conductivity and dipole neutralization. Dipole neutralization losses are detected by kinematic viscosity and frequency. An electron increase of dipole neutralization losses on frequency is monitored in the event of inherent oils. However, dissipation factor of natural ester can meet the critical values set for mineral oil [18].

Dissipation factor of natural oils can be slightly lowered by adding significant amount of mineral compound [19]. My experiment proved that $20 \%$ of mineral compound in mixture still provides excellent biodegradability in closed bottle test. Temperature dependence of dissipation factor of mixture based on palm oil is shown in figure 3 .

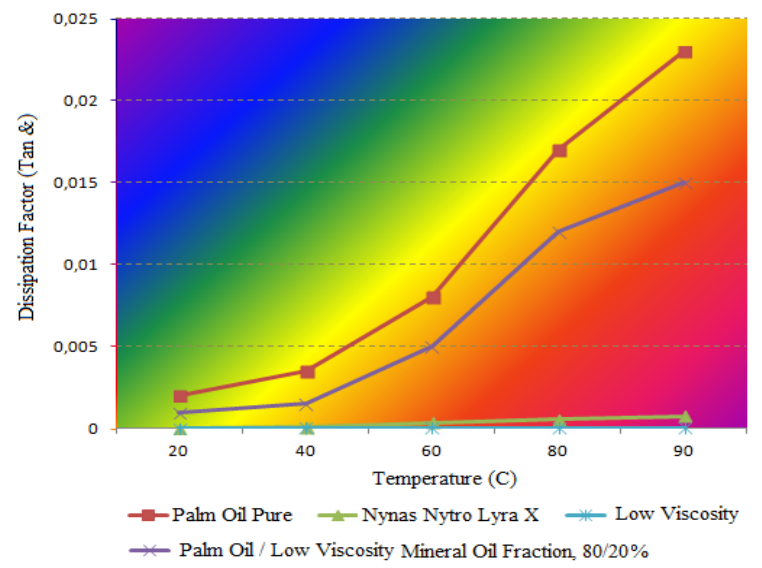

Figure 3. Temperature dependence of dissipation factor of mixture based on palm oil 
When mixing mineral compound with natural oil, the special bacteria reduce the inherent oil at first, which efficiencies in raising the operative surface submitted to oxidative enzymes. Scarcely violable molecules of substance oil are decomposed and crumbled; thereby they are easily obtainable by oxidative enzymes. Finally, it is feasible to use rock oil in higher volume ratios while preserving biodegradability. Biodegradability of ester liquids with mineral compound mixtures is shown in figure 4 .

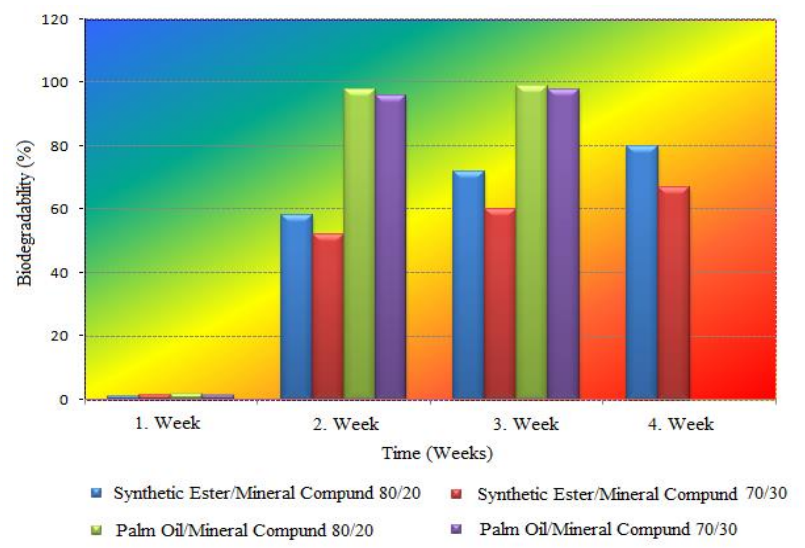

Figure 4. Biodegradability of ester liquids with mineral compound mixtures

\section{INTERFACIAL TENSION}

Interfacial tension is one of the weak points of natural esters. As the oxidative atmosphere and elevated temperature are present, natural oils tend to thicken. The answer is again in the chemical structure, where polymerization takes place and each ester molecules are bonding together to form longer chains. Hence the oil is getting thicken and losses its cooling function. However, with proper additives, natural oils may improve its interfacial tension. A simple experiment has been performed using Shell Diala S3 ZX-I, Nynas Nytro Lyra $\mathrm{X}$, and Power Oil 1020-60 UX tester.

Mineral, synthetic and natural oils have been compared. Mineral oils are composed of hydrocarbons and just on bonds between carbon and hydrogen oxidation reactions are taking place. This is accelerated by heat or light oxidation product later undergoes subsequent reaction as polymerization or condensation reaction therefore acid number and viscosity of oil is increased. The stability is evaluated according to the degree of deterioration of the electrical, physical or chemical properties such as dissipation factor, the interfacial tension at the interface of water-oil, and others.

The copper slice is loaded into the oil. The oil in sealed container is heated to a predefined temperature, which must be open for 1 minute after 24 hours of heating of oil. Mineral oil has been tested using temperature $160^{\circ} \mathrm{C}$, $600(\mathrm{kPa})[20]$ and cerium steerage as tension stabilizer. Interfacial tension machine is shown in figure 5 . Interfacial tension results of various oil types are shown in table 6 .

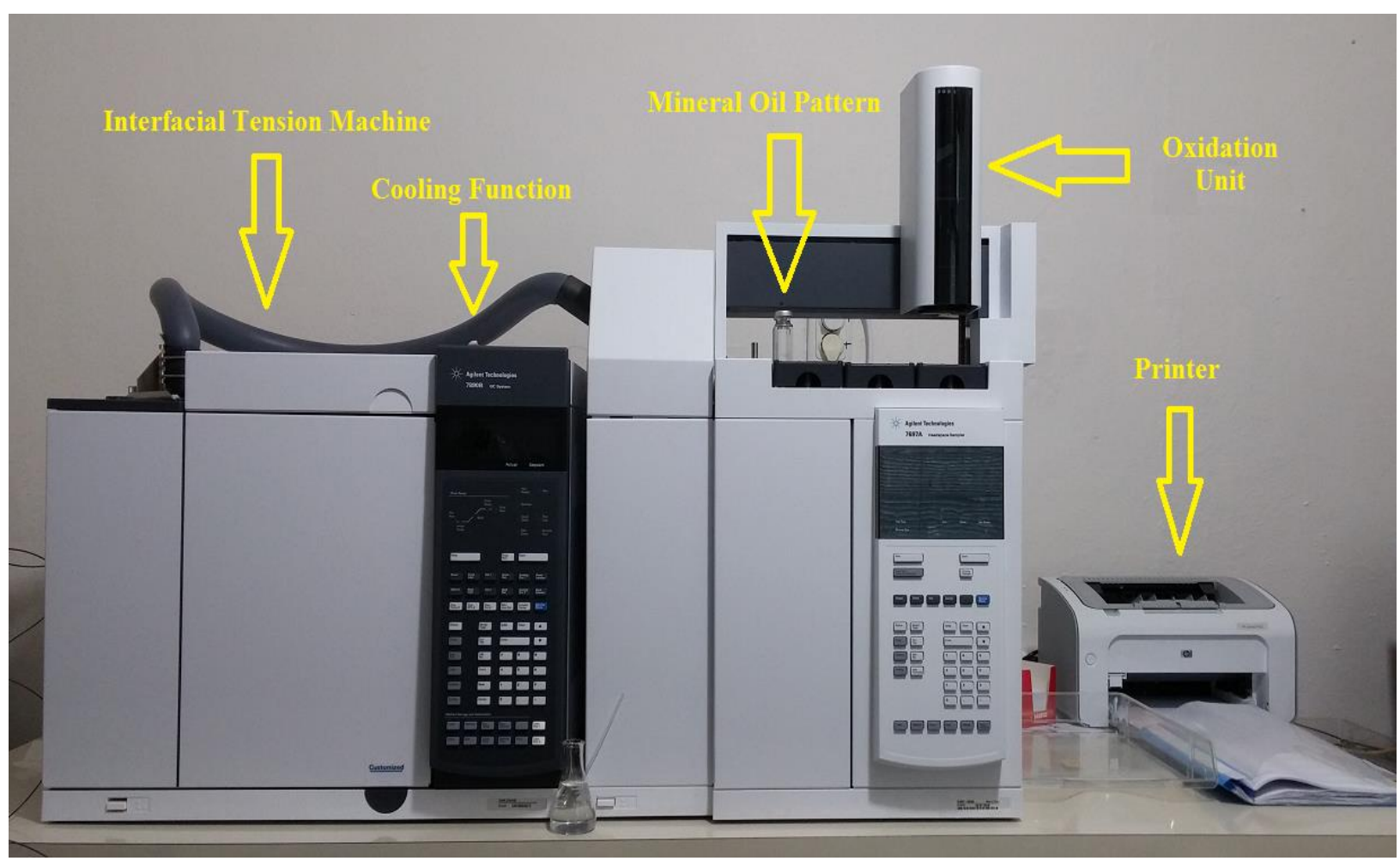

Figure 5. Interfacial tension machine 
Table 6. The interfacial tension results of various oil types [20]

\begin{tabular}{|c|c|c|}
\hline Type of Oil & Inhibitor & Interfacial Tension \\
\hline Nynas Nytro Lyra X & Inhibited Oil & 87 \\
\hline Nynas Nytro Lyra X regeneration & Inhibited Oil & 184 \\
\hline Power Oil 1020-60 UX & Inhibited Oil & 216 \\
\hline Shell Diala S3 ZX-I & Inhibited Oil & 129 \\
\hline Shell Diala D & No Inhibitor & 99 \\
\hline Shell Diala D regeneration & Inhibited Oil & 245 \\
\hline Synthetized Ester 22 & No Inhibitor & 53 \\
\hline Synthetized Ester 22 & Phenolic $0.4 \%$ & 253 \\
\hline Synthetized Ester 22 & Amine $0.4 \%$ & 1110 \\
\hline Synthetized Ester $22+20 \% \mathrm{HClO}$ & No Inhibitor & 25 \\
\hline Synthetized Ester $22+20 \% \mathrm{HClO}$ & Phenolic $0.4 \%$ & 170 \\
\hline Synthetized Ester $22+20 \% \mathrm{HClO}$ & Amine $0.4 \%$ & 969 \\
\hline Environmental Temp FR3 & - & 75 \\
\hline Soybean Oil & No Inhibitor & 54 \\
\hline Soybean Oil & Phenolic $0.4 \%$ & 262 \\
\hline Soybean Oil & Phenolic $0.8 \%$ & 353 \\
\hline Soybean Oil & Amine $0.2 \%$ & 60 \\
\hline Soybean Oil & Amine $0.4 \%$ & 60 \\
\hline Palm Oil & No Inhibitor & 36 \\
\hline Palm Oil & Phenolic $0.4 \%$ & 166 \\
\hline Palm Oil & Phenolic $0.8 \%$ & 216 \\
\hline Palm Oil & Amine $0.2 \%$ & 41 \\
\hline Palm Oil & Amine $0.4 \%$ & 45 \\
\hline Palm Oil & Amine $0.8 \%$ & 45 \\
\hline
\end{tabular}

As criteria was used pressure drop of $10 \%$. Synthetic esters have been tested using the same procedure. Subjected synthetic ester is a mixture of various hydrocarbons with viscosity of $22\left(\mathrm{~mm}^{2} / \mathrm{s}\right)$. Both amine and phenol antioxidants have been added. Natural oils were tested under lower temperature $\left(130^{\circ} \mathrm{C}\right)$ and no oxidative catalyst was used.

\section{WATER CONTENT}

One of the great differences between traditionally used mineral oils and proposed alternatives is the ability to absorb moisture. In past, it was shown, that saturation limit of natural oils is over $1000 \mathrm{ppm}$ of water at $20^{\circ} \mathrm{C}$, while mineral oils are fully saturated at $30-60 \mathrm{ppm}$ (depend on particular oil). Saturation limit for mineral oils and ester insulating liquids chart is shown in figure 6.

This phenomenon is caused by differences in chemical structure. As natural oils are slightly polar, they bond water molecules by electrostatic forces and prevails drying. The simplified chemical model for polar glycolipids is shown in figure 7 .

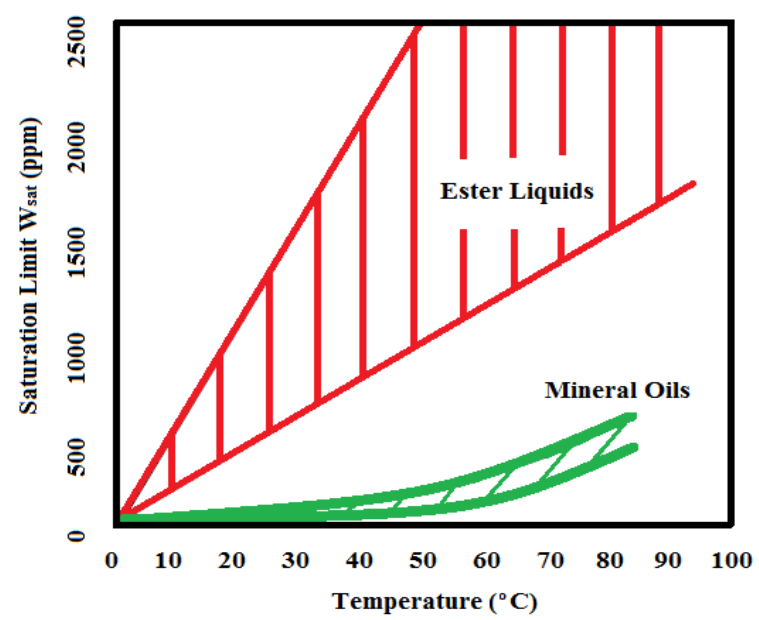

Figure 6. Saturation limit for mineral oils and ester insulating liquids chart 
<smiles>[R3]C(=O)OC[C@H](COC([R])([R])[R])[C@H](CC)OC([R])=O</smiles>

Figure 7. The simplified chemical model for polar glycolipids by electrostatic forces

When dried using standardized hot oven procedure, mineral oils lose their water content easily. Widely used procedure is to heat up the oil to the temperature class $\left(110^{\circ} \mathrm{C}\right.$ for class number 1$)$ and leave in circulating air for 1 hour at least. Water content by this procedure reduces to approx. 5-10 ppm. By the same procedure in natural oils water content reduces to approx. 100-200 ppm, depending on the particular oil composition. The similar behavior was observed in case of synthetic esters, however, their molecules are not as complex and further exhibit less dipole moments, and hence they are dried more easily.

It was monitored that even after long term of hot-air dehydration the humidity substance under specific grade in inherent based on esters has no trends to vaporize. Of course it is feasible to dehydration the mineral oil further, e.g. using particle sieve with suitable net sizes, however this method is not appropriate for industrial use and moreover powder molecules from the sieve are getting into the mineral oil, affecting electrical features or vacuum. The positive effect of this behavior is that both esters and mineral oils act similarly when relative moisture is concerned. The relative moisture [21] is given by equation 1 .

$$
W_{r e l}=\frac{W_{a b s}}{W_{s a t}}
$$

In equation $1, \mathrm{~W}_{\mathrm{abs}}$ is absolute water content (ppm) and $\mathrm{W}_{\text {sat }}$ is saturation limit (ppm). When e.g. breakdown voltage dependence on relative moisture content is plotted, the curves for mineral oil and ester based insulating liquids are very close. Thus ester based insulating liquids may be used in applications, where moisture causes troubles. Especially esters can be recommended for small distribution transformers, which are not equipped with dehydrators.

\section{CONCLUSIONS}

As alternative insulating liquids behave differently than traditionally used mineral oils, their behavior in insulating system must be examined experimentally. Some researches focuses on acidity of oils [19] and others prove low impact on de-neutralization factor of paper in the system. Main problems are dielectric properties of mineral oil and oxidative stability. Hermetic power transformers are required when natural esters are to be used. However also proper antioxidants can improve this feature as presented, and here is the same problem as with the absence of critical values of electric parameters there is not standardized technique for oxidation stability testing of natural esters. Finally, possibilities of establishing of critical values of parameters for natural esters are partially presented in the paper.

\section{REFERENCES}

1) Perkasa, C.Y., Lelekakis, N., Czaszejko, T., Wijaya, J., Martin, D., "A comparison of the formation of bubbles and water droplets in vegetable and mineral oil impregnated transformer paper", IEEE Transactions on Dielectrics and Electrical Insulation, 21(5): 2111-2118, (2014).

2) Pamuk, N., "Investigation of the usage of palm oils with the aim of insulation in high voltage power system equipments", Technical Gazette, 22(5): 1287-1296, (2015).

3) Tenbohlen, S., Koch, M., "Aging performance and moisture solubility of vegetable oils for power transformers", IEEE Transactions on Power Delivery, 25(2): 825-830, (2010).

4) Ruijin, L., Jian, H., Chen, G., Zhiqin, M., Lijun, Y., “A comparative study of physicochemical, dielectric and thermal properties of pressboard insulation impregnated with natural ester and mineral oil", IEEE Transactions on Dielectrics and Electrical Insulation, 18(5): 16261637, (2011).

5) Lelekakis, N., Martin, D., Wijaya, J., “Ageing rate of paper insulation used in power transformers part 1: oil / paper system with low oxygen concentration", IEEE Transactions on Dielectrics and Electrical Insulation, 19(1): 1999-2008, (2012).

6) Lundgaard, L.E., Hansen, W., Linhjell, D., Painter, T.J., "Aging of oil-impregnated paper in power transformers", IEEE Transactions on Power Delivery, 19(1): 230-239, (2004).

7) Sander, A., Kardum, J.P., "Pentaerythritol crystallization - influence of the process conditions on the granulometric properties of crystals", Advanced Powder Technology, 23(2): 191-198, (2012).

8) Pamuk, N., "Investigation of the long term degradation of cellulosic insulating materials in high voltage power transformer", Journal of Optoelectronics and Advanced Materials, 16(3-4): 422-428, (2014).

9) Griffin, P., Lewand, L., Heywood, R., Lapworth, J., "Gassing characteristics of transformer oils at modest temperatures part 1: transformer experiences", Doble Conference, Boston, USA, 43-51, (2004).

10) IEC 60422/2013 International Standard, "Mineral Insulating Oils in Electrical Equipment - Supervision and Maintenance Guidance", International Electrotechnical Commission, (2013).

11) Oommen, T.V., Prevost, T.A., "Cellulose insulation in oil-filled power transformers: part II: maintaining insulation integrity and life", IEEE Electrical Insulation Magazine, 22(1): 5-14, (2006).

12) IEC 1203/1905 International Standard, "Synthetic Organic Esters for Electrical Purposes - Guide for Maintenance of Transformer Esters in Equipment", International Electrotechnical Commission, (2013). 
13) Janes, A., Lust, E., “Organic carbonate - organic ester based non-aqueous electrolytes for electrical double layer capacitors", Electrochemistry Communications, 7(5): 510-514, (2005)

14) IEC 61099/2010 International Standard, "Insulating Liquids - Specifications for Unused Synthetic Organic Esters for Electrical Purposes", International Electrotechnical Commission, (2010).

15) Adejumobi, I.A., Oyagbirin, S.G., "Insulation deterioration and its effects on power systems", Journal Engineering and Applied Sciences, 2(5): 870-873, (2007).

16) Gallagher, T.J., "Simple dielectric liquids - mobility, conduction and breakdown", Clarendon Press, Oxford, 59-63, (1975).

17) Gernandt, R., Wagberg, L., Gardlund, L., Dautzenberg, H., "Polyelectrolyte complexes for surface modification of wood fibres part-I: preparation and characterization of complexes for dry and wet strength improvement of paper", Colloids and Surfaces A: Physicochemical and Engineering Aspects, 213(1): 15-25, (2003).
18) Pamuk, N., "Statistical analysis of electrical and mechanical breakdown stress for insulation performance in high voltage power transformer", Technical Gazette, 21(3): 495-503, (2014).

19) Radakovic, Z.R., Sorgic, M.S., "Basics of detailed thermal-hydraulic model for thermal design of oil power transformers", IEEE Transactions on Power Delivery, 25(2): 790-802, (2010).

20) Pamuk, N., "Investigation of destructive and healing effects on the temperature and moisture rise in terms of dielectric strength of transformer insulation oil", International Journal of Scientific and Technological Research, 1(10): 20-31, (2015).

21) Han, S., Li, Q., Li, C., Yan, J., "Electrical and mechanical properties of the oil-paper insulation under stress of the hot spot temperature", IEEE Transactions on Dielectrics and Electrical Insulation, 21(1): 179-185, (2014). 